\title{
O Que Pode a Psicologia Social no Presente?
}

\author{
What Can Social Psychology do Nowadays? \\ Qué Puede la Psicología Social en el Presente?
}

\begin{abstract}
Luciano Bedin Costa
Rosane Azevedo Neves Silva

Universidade Federal do Rio Grande do Sul (UFRGS), Porto Alegre, RS, Brasil
\end{abstract}

Este dossiê é dedicado à memória da amiga e colega Tania Mara Galli Fonseca, que tanto nos inspirou a pensar-viver possíveis à Psicologia Social.

Em 25 de outubro de 2019 promovemos a $6^{a}$ edição do evento Temas em Debate, uma iniciativa do Programa de Pós Graduação em Psicologia Social e Institucional da Universidade Federal do Rio Grande do Sul - UFRGS. Este evento tem como marca a socialização de escritas coletivas produzidas por doutorandas e doutorandos do respectivo programa, alicerçadas em torno de temas comuns. O grupo responsável por cada Temas em Debate é constituído por docentes e estudantes matriculados na disciplina de Teorias e Métodos III, disponibilizada de forma eletiva no currículo das turmas de doutorado de nossa instituição. Ao longo de um semestre, a(o)s estudantes matriculada(o)s são instigada(o)s a pensar em um tema de interesse grupal, dividindose em grupos na produção de artigos que possam movimentá-lo. As produções dos grupos são lidas e discutidas coletivamente ao longo dos encontros, de modo que a(o)s participantes possam experenciar não somente a escrita, como também a leitura dos textos da(o)s colegas. O resultado das produções escritas é compartilhado no evento Temas em Debate, contando com a leitura de pesquisadora(e)s escolhidos pelos próprios grupos. Esta(e)s leitora(e)s especiais são convidada(o)s a participar do evento produzindo um texto em ressonância ao artigo a ela(e)s submetido. O resultado destas produções, sejam estas 
$\mathrm{da}(\mathrm{o}) \mathrm{s}$ estudantes quanto $\mathrm{da}(\mathrm{o}) \mathrm{s}$ debatedora(e)s são publicados anualmente em dossiês da Revista Polis e Psique.

Em 2019 nossa turma contou com doze estudantes matriculada(o)s, que se dividiram em três grupos, a partir de uma temática que nos parecia e ainda nos parece bastante provocadora: "o que pode a Psicologia Social no presente?". Fazendo um resgate das condições de emergência desta temática, lembramos do quanto estávamos mobilizada(o)s pelo suposto "fracasso social" referente aos retrocessos tonalizados pelo "espírito reformista" das políticas públicas até então vigentes, acentuadas a partir do impeachment da presidenta Dilma Rousseff, da aprovação da PEC55/2016 (conhecida também como a "PEC do fim do mundo"), culminando no resultado das eleições presidenciais de 2018. Enquanto no processo de impeachment lutávamos por uma certa resistência democrática, com as eleições presidenciais de 2018 vimos a própria democracia ser arrastada ao seu avesso mais sombrio. Contudo, a sensação de fracasso social nos acometia muito em função dos próprios meios a que chegávamos a este avesso, meios democraticamente legitimados, diga-se de passagem. Em nossa disciplina de Teorias e Métodos III seguidamente nos víamos enredados a perguntas do tipo "Onde foi que erramos?", relacionadas não diretamente a um fracasso do pensamento de esquerda, mas de um modo de pensar a realidade calcado em conceitos vinculados à justiça social, gestão democrática e respeito às diferenças. Ao evocarmos a pergunta "Onde foi que erramos?" nos víamos convocados a pensar que "nós" era este que respondia por tal enunciado. Por certo não era o "nós" representado pelos 57,8 milhões de eleitores que endossaram a vitória do presidente. Mesmo que ideologicamente não fizéssemos parte desta significativa parcela da população responsável pela eleição do presidente em questão, compreendíamos ser também nossa a paradoxal fratura aberta através do acontecimento eleitoral. Em outras palavras, era também nossa a responsabilidade pelo estado de coisas a que nos encontrávamos. Inevitável não retomarmos à máxima deleuze guattariana expressa a partir da questão "como pode o desejo desejar sua própria repressão?”. Em termos políticos, a assunção democrática de um governo explicitamente antidemocrático nos parecia algo inconjugável, levando-nos a pensar que, enquanto psicólogos sociais, a própria psicologia social deveria também ser colocada em questão. Se por um lado nos 
parecia imprescindível problematizar o absurdo a que chamávamos de presente, por outro nos parecia igualmente relevante investigar como este presente supostamente absurdo repercutia nos corpos daquelas e daqueles que, como nós, tentavam entendê-lo. Se durante um período de nossa história pregressa perguntávamos pela identidade da Psicologia Social, hoje nos parece outra a pergunta a ser feita. Ao invés de "o que é a Psicologia Social?”, sentença que nos convoca a uma espécie de ontologia epistêmica, nos vemos confrontada(o)s a pensar “o que pode a Psicologia Social?”, pergunta que inexoravelmente nos projeta a horizontes possíveis, exigindo de nós, psicóloga(o)s sociais, um posicionamento mais assertivo diante dos mesmos. Assim, ao perguntarem sobre "O que pode a psicologia social no presente?", a(o)s doutoranda(o)s se viram convocada(o)s a produzir escritas que pudessem ser dignas de suas próprias provocações. O resultado destas produções pode ser conferido na leitura dos seis artigos que compõem este dossiê; três destes assinados pela(o)s respectiva(o)s estudantes, e três produzidos pelas suas respectivas debatedoras.

$\mathrm{O}$ evento, realizado no Instituto de Psicologia da UFRGS, foi dividido em três blocos, divisão mantida na organização deste dossiê. O primeiro bloco iniciou com a leitura do artigo "Do paradigma ao paradoxo ético-estético-político: por uma radicalização da psicologia social", de Daniel Boianovsky Kveller, Daniel Rodrigues Fernandes, Diego Drescher de Castro e Renata Flores Trepte. Dentre as inúmeras provocações articuladas ao longo do texto, destacamos a maneira como conclui, afirmando que "a psicologia social deve se valer deste presente para radicalizar os seus pressupostos, rompendo com a ideia de um paradigma éticoestético-político em favor de um paradoxo ético-estético-político". Este texto foi lido pela professora Alice De Marchi Pereira de Souza que, juntamente com Karine Shamash Szuchman, produziram o artigo "Furando os bolsos da psicologia social: experimentações transgressoras na docência". Neste texto as autoras apresentam a experiência de uma sala de aula a partir das políticas afirmativas, propondo-se a pensar a docência em psicologia social e seus agires transgressores.

O segundo bloco do evento iniciou com a apresentação do artigo "O ato de narrar e a produção de conhecimento em Psicologia Social", de Bruna Moraes Battistelli, Erica Franceschini, Flávia Luciana Magalhães Novais e Willian 
Guimarães. O texto se situa a partir de uma aposta metodológica pautada pelo viés interseccional, movimentado a partir de narrativas de mulheres. A debatedora foi feita pela professora Amana Rocha Mattos que, com Geórgia Marcinik, produziram o artigo "Movimentos feministas e relações raciais intragênero: entre a luta e a opressão", em ressonância direta com as provocações levantadas pelo texto a elas oferecido.

O último bloco do evento contou com a leitura de "O Que Pode A Psicologia Social Com relação ao Presente?", produzido por Paula Flores, Helena Soares; Giovana Barbieri Galeano e Robert Filipe dos Passos. O leitor é apresentado a uma problematização da Psicologia Social onde o dito "social" se situa enquanto efeito das tensões de saber e poder, acentuadas a partir dos acontecimentos sócio-políticos referentes ao biênio 2018-2019. A comentadora foi a professora Cristina Ribas, produzindo um contundente ensaio que já em seu título nos convoca à ação: "Não vamos obedecer. O comando do ódio no Brasil de hoje".

Esta edição do Temas em Debate foi dedicada à memória da professora Tania Mara Galli Fonseca, uma das fundadoras do Programa de Pós Graduação em Psicologia Social e Institucional da
UFRGS, pesquisadora que se confunde com a própria história da Psicologia Social no Brasil. Lembramos com carinho da belíssima homenagem produzida por integrantes do seu grupo de pesquisa, que realizaram a leitura de um texto que nos deixou bastante emocionada(o)s. Achamos que seria bonito publicarmos esta homenagem delicadamente intitulada "Um céu estrelado. Como acreditar um mundo sem nós? Manifesto como céu de amor irreversível", disponível ao final desta compilação.

Abraçada(o)s a tais afetos moventes que convidamos à leitura deste dossiê, na aposta de uma Psicologia Social capaz não somente de ler, mas de agir com este presente, mesmo que a imagem disponível no momento seja a de seu avesso assustador.

Luciano Bedin da Costa Rosane Azevedo Neves da Silva Editores convidados

Luciano Bedin Costa é professor do Programa de Pós Graduação em Psicologia Social e Institucional da UFRGS.

E-mail:bedin.costa@gmail.com 
ORCID:http://orcid.org/0000-0002-6350-

$\underline{2644}$

Rosane Azevedo Neves Silva é docente do

PPP Psicologia Social e Institucional da UFRGS.

E-mail:rosane.neves@ufrgs.br

ORCID:http://orcid.org/0000-0001-6486-

$\underline{0630}$

Submissão: $22 / 10 / 2020$

Aceite: $20 / 11 / 2020$ 